\title{
Two new Tapinocyba Simon, 1884 from the highlands of Nepal (Aranei: Linyphiidae)
}

\section{Ава новых вида рода Tapinocyba Simon, 1884 из высокогорий Непала (Aranei: Linyphiidae)}

\section{Andrei V. Tanasevitch \\ A.B. Танасевич}

A.N. Severtsov Institute of Ecology and Evolution, Russian Academy of Sciences, Leninsky prospekt 33, Moscow 119071, Russia. E-mail: tanasevitch@gmail.com

Институт проблем экологии и эволюции им. А.Н. Северцова РАН, Ленинский проспект 33, Москва 119071, Россия.

KEY WORDS: taxonomy, spiders, Erigoninae, new species, Himalayas.

КЛЮЧЕВЫЕ СЛОВА: таксономия, пауки, Erigoninae, новые виды, Гималаи.

ABSTRACT. Two new species, Tapinocyba montivaga sp.n. and T. altimontana sp.n., are described from the highlands of the Nepal Himalayas. Both species clearly differ from each other, as well as from the known congeners, by certain structural details of their genitalia.

How to cite this article: Tanasevitch A.V. 2019. Two new Tapinocyba Simon, 1884 from the highlands of Nepal (Aranei: Linyphiidae) // Arthropoda Selecta. Vol.28. No.2. P.305-308. doi: 10.15298/arthsel. 28.2 .13

РЕЗЮМЕ. Два новых вида, Tapinocyba montivaga sp.n. и T. altimontana sp.n., описаны из высокогорий Гималаев, Непал. Оба вида хорошо отличаются как друг от друга, так и остальных представителей рода деталями строения гениталий.

\section{Introduction}

The genus Tapinocyba Simon, 1884 is considered as Holarctic (see Tanasevitch [2018]), containing only two known species which occur near the border of the Palaearctic and Oriental regions, i.e., Tapinocyba emei Tanasevitch, 2018 (Sichuan, China) and T. formosa Tanasevitch, 2011 (Taiwan). Another two species from near the border of these realms were revealed in the spider material collected by Prof. J. Martens in the Himalayas during his numerous expeditions to Nepal. No representatives of Tapinocyba have hitherto been recorded from the Himalayas. Descriptions of these two new species are given below.

\section{Material and methods}

This paper is based on the spider material taken by J. Martens and W. Schawaller in Nepal, kept in the Sencken-

Results of the Himalaya Expeditions of J. Martens, No. $286-$ J.M. sponsored by Deutscher Akademischer Austauschdienst and Deutsche Forschungsgemeinschaft. berg Museum, Frankfurt am Main, Germany (SMF). The sample number is given in square brackets. All specimens are preserved in $70 \%$ ethanol and studied using a MBS-9 stereo microscope. A Levenhuk C-800 digital camera was applied for taking some photographs. Images taken at multiple focal planes were combined with the help of Helicon Focus image stacking software, version 5.1. The sequence of leg segment measurements is as follows: femur + patella + tibia + metatarsus + tarsus. All measurements are given in millimeters. The chaetotaxy is given in a formula, e.g., 1.1.1.1, which refers to the number of dorsal spines on tibiae I-IV. Scale lines in the figures correspond to $0.1 \mathrm{~mm}$ unless indicated otherwise. The terminology of copulatory organs mainly follows that of Merrett [1963], Hormiga [2000] and Holm [1979].

The following abbreviations are used in the text and figures: a.s.l. - above sea-level; DSA — distal suprategular apophysis sensu Hormiga [2000]; E - embolus; MM median membrane sensu van Helsdingen [1965] = embolic membrane sensu van Helsdingen [1986] and Hormiga [1994]; $\mathrm{P}$ - paracymbium; Pr — protegulum sensu Holm [1979]; $\mathrm{R}$ - radix; RA — radical apophysis; TmI — position of trichobothrium on metatarsus I; TP - tailpiece (a proximal part of the radix) sensu Crosby, Bishop [1925].

\section{Description}

\section{Tapinocyba montivaga sp.n.}

Figs 1, 3-6.

HOLOTYPE O $0^{7}$ (SMF), NEPAL, Sankhua Sabha District, between passes Meropapa La and Pomri La, 4300-4400 m a.s.l., alpine meadows, dwarf Rhododendron, 28.V.1988, leg. J. Martens \& W. Schawaller [No. 396].

PARATYPE OT $^{\top}$ (SMF), Sankhua Sabha District, descent from Pomri La, S slope, pastures, 4100-4400 m a.s.1., 29.V.1988, leg. J. Martens \& W. Schawaller [No. 399].

NAME. The specific name is a Latin adjective meaning "wandering in the mountains".

DIAGNOSIS. The new species differs from the known congeners by the relatively long embolus, the well-developed tailpiece of the radix, as well as by the shape of the retrolateral tibial outgrowth. From the other Himalayan species described below, T. montivaga sp.n. is distinguished by 

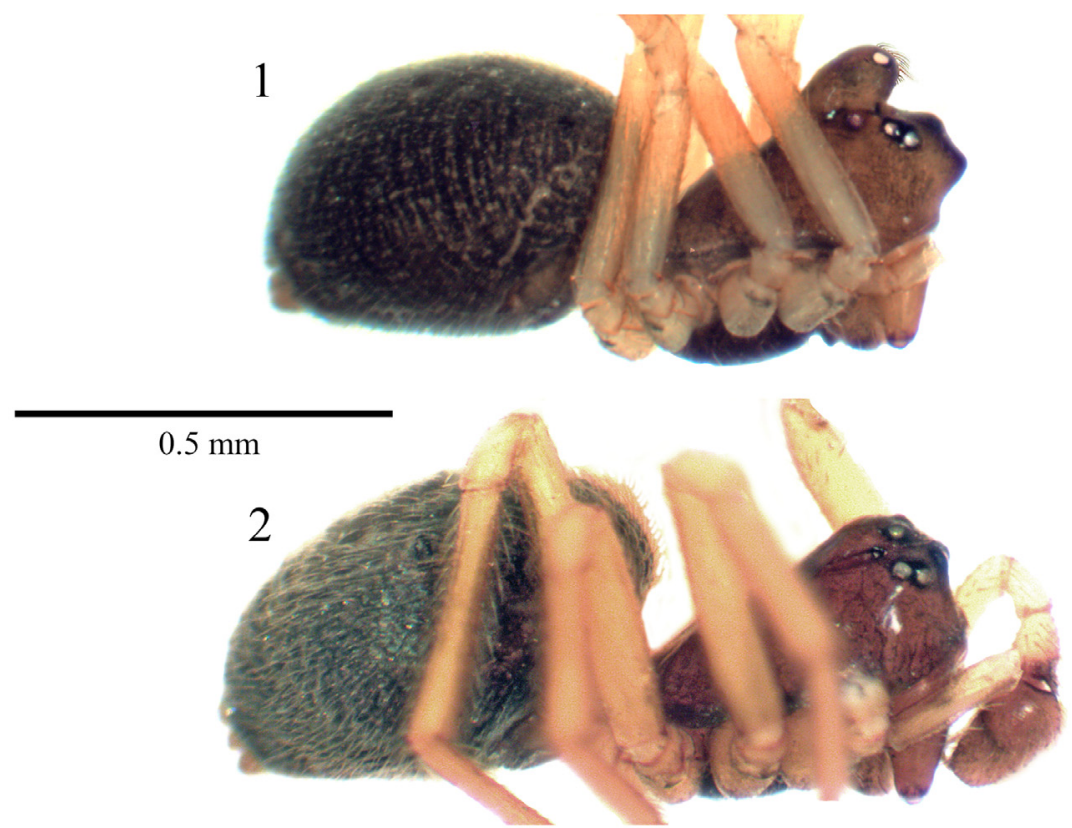

Figs 1, 2. Pictures of Tapinocyba montivaga sp.n. (1), O paratype, and T. altimontana sp.n. (2), O paratype. 1, 2 - body, lateral view.

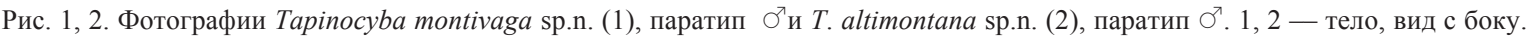
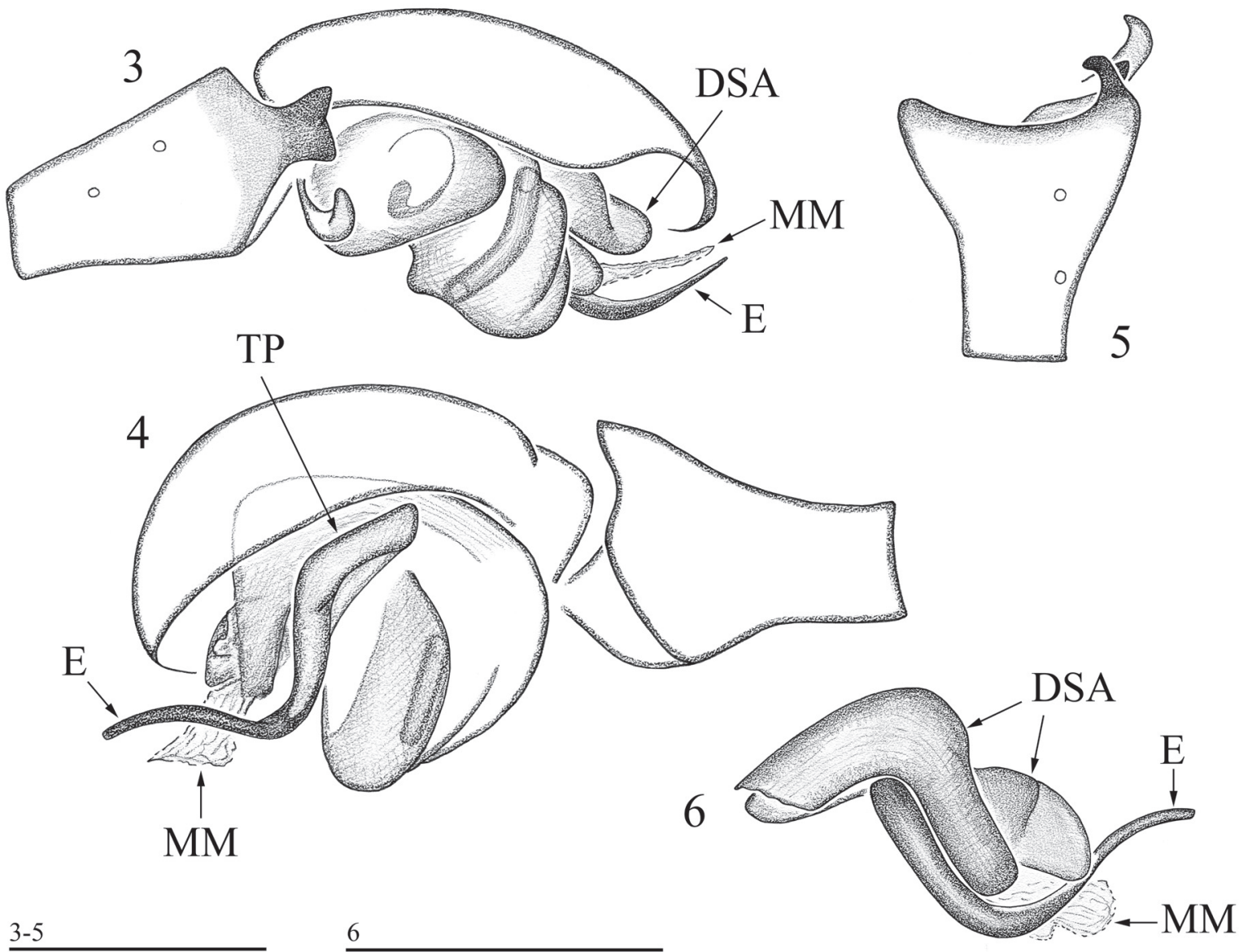

Figs 3-6. Details of palpal structure of Tapinocyba montivaga sp.n., $0^{7}$ paratype. 3, 4 - right palp, retrolateral and prolateral views, respectively; 5 - palpal tibia, dorsal view; 6 - distal suprategular apophysis and embolus.

Рис. 3-6. Детали строения пальпы Tapinocyba montivaga sp.n., паратип O’. 3, 4 - правая пальпа, ретро- и пролатерально, соответственно; 5 - голень пальпы, вид сверху; 6 - дистальная супратегулярная апофиза и эмболюс. 


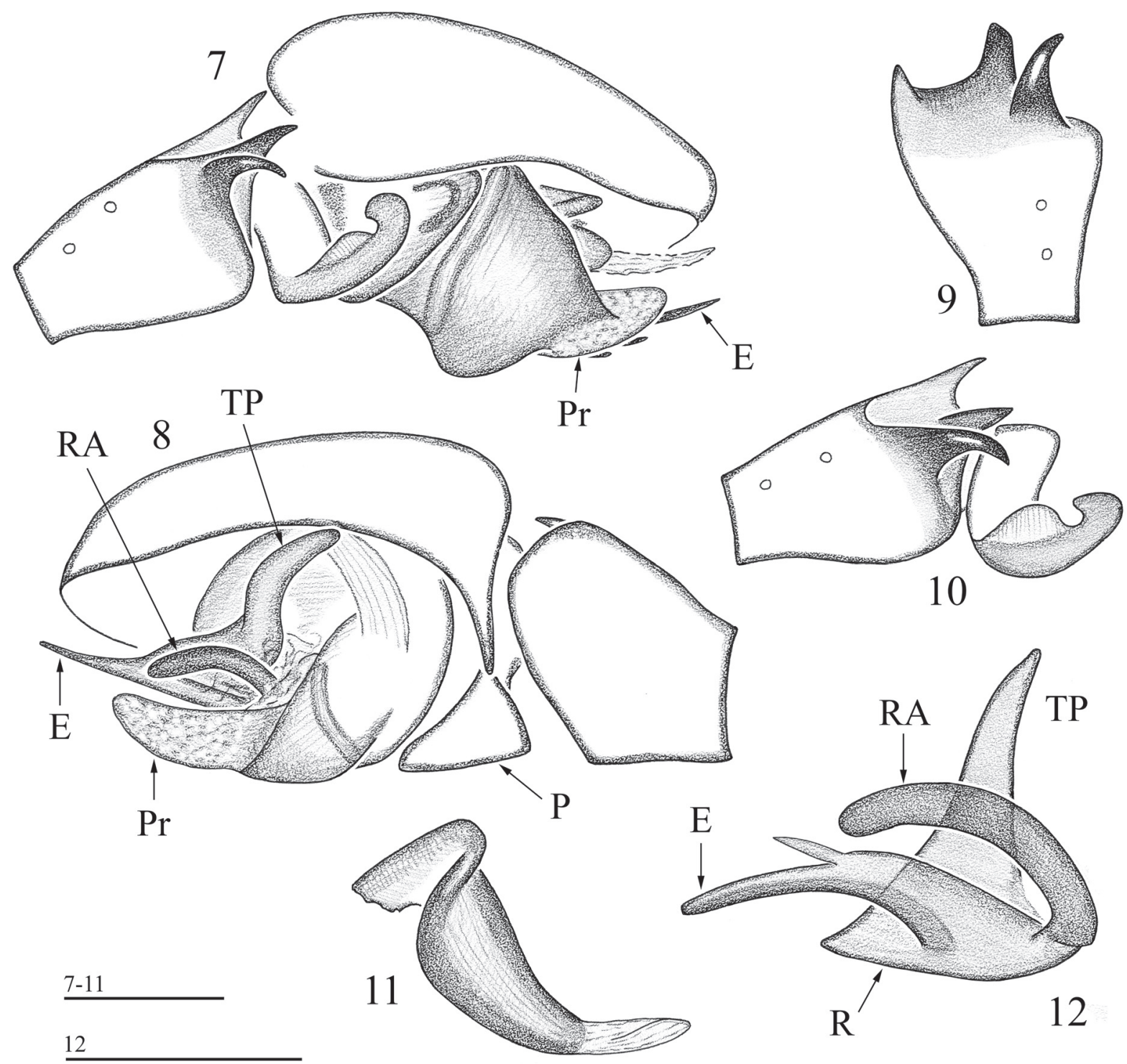

Figs 7-12. Details of palpal structure of Tapinocyba altimontana sp.n., $0^{7}$ paratype. 7, 8 - right palp, retrolateral and prolateral views, respectively; 9 - palpal tibia, dorsal view; 10 - palpal tibia and paracymbium, retrolateral view; $11-$ distal suprategular apophysis; 12 - embolic division.

Рис. 7-12. Детали строения пальпы Tapinocyba altimontana sp.n., паратип о7. 7, 8 - правая пальпа, ретро- и пролатерально, соответственно; 9 - голень пальпы, вид сверху; 10 - голень пальпы и парацимбиум, вид сбоку; 11 - дистальная супратегулярная апофиза; 12 - эмболюсный отдел.

the shape of both the carapace and palpal tibia, the absence of a protegulum, as well as by the lack of a radical apophysis in the embolic division.

DESCRIPTION. Male paratype. Total length 1.69. Carapace 0.70 long, 0.55 wide, dark brown, modified as shown in Fig. 1. Head part of carapace with a slightly bipartite elevation, each part carrying a posterior median eye. Eyes not enlarged, normal. Sulci present, small. Chelicerae 0.23 long, a mastidion absent. Legs pale brown. Leg I, 1.89 long $(0.55+0.18+0.43+0.40+0.33), \mathrm{IV}, 1.91$ long $(0.55+$ $0.18+0.48+0.40+0.30)$. Chaetotaxy 1.1 .1 .1 , spines very short, poorly visible. Metatarsi I-III each with a trichobothrium. TmI, 0.57. Palp (Figs 3-6): Patella short. Tibia elongated, with a retrolateral, wide, somewhat bifid out- growth. Paracymbium very small, hook-shaped. Distal suprategular apophysis relatively large, complex. Median membrane short and wide. Radix elongated, slightly bent; tailpiece well-developed, narrow. Embolus relatively long, curved. Abdomen 0.88 long, 0.60 wide, black.

Female unknown.

DISTRIBUTION. Known only from two localities in the highlands of Nepal, at 4100-4400 m a.s.l.

\section{Tapinocyba altimontana sp.n.}

Figs 2, 7-12.

HOLOTYPE (SMF), NEPAL, Sankhua Sabha District, descent from Pomri La, S slope, 4550-4450 m a.s.l., on snow cover, 29.V.1988, leg. J. Martens \& W. Schawaller [No. 398]. 


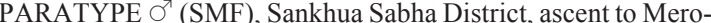
papa La from Gabri Khola, S of Thudam, 4300-4600 m a.s.1., meadows with dwarf Rhododendron, 26.V.1988, leg. J. Martens \& W. Schawaller [No. 393].

NAME. The specific name is a Latin adjective meaning a " high-mountain dweller".

DIAGNOSIS. The new species is distinguished from the known congeners by very characteristic apophyses on the palpal tibia that resemble those in some Nepalese Oedothorax Bertkau, 1883, e.g., O. lucidus Wunderlich, 1974 or $O$. unicolor Wunderlich, 1974. Tapinocyba altimontana sp.n. is also diagnosed by the presence of a peculiar radical apophysis at the base on the embolus. The differences from $T$. montivaga sp.n. see above.

DESCRIPTION. Male paratype. Total length 1.95. Carapace 0.88 long, 0.75 wide, dark brown, modified as shown in Fig. 2. Head part of carapace slightly elevated. Eyes not enlarged, normal. Sulci present, small. Chelicerae 0.33 long, a mastidion absent. Legs pale brown. Leg I, 2.51 long $(0.70$ $+0.25+0.63+0.55+0.38)$, IV, 2.81 long $(0.75+0.28+$ $0.70+0.65+0.43)$. Chaetotaxy 1.1.1.1, length of spines 0.5-1 diameter of leg segment. Metatarsi I-III each with a trichobothrium. TmI 0.61. Palp (Figs 7-12): Patella short. Tibia distally with three apophyses, a retrolateral one clawshaped. Paracymbium relatively large, with a rounded ridge in the middle. Tegulum ending up in a well-protruded and membraneous protegulum. Distal suprategular apophysis relatively large, gradually narrowing distad, ending up in an elongated membrane. Median membrane probably reduced. Tailpiece well-developed, distal part of radix with a gradually bent apophysis at base of embolus. Embolus equipped with a short and sharp process in the middle. Abdomen 1.13 long, 0.90 wide, black.

Female unknown.

DISTRIBUTION. Known only from two localities in the highlands of Nepal, at $4300-4600 \mathrm{~m}$ a.s.1.
Acknowledgements. I am grateful to Jochen Martens (Mainz, Germany) for providing the material he collected during his expeditions in the Himalayas, to Peter Jäger and Julia Altmann (both SMF), who supplied me with the samples under their care. I also thank Sergei I. Golovatch (Moscow) who kindly checked the English of an advanced draft.

\section{References}

Crosby C.R., Bishop S.C. 1925. Studies in New York spiders; Genera: Ceratinella and Ceraticelus // New York State Museum Bulletin. Vol.264. P.1-71.

Helsdingen P.J. 1965. Sexual behaviour of Lepthyphantes leprosus (Ohlert) (Araneida, Linyphiidae), with notes on the function of the genital organs // Zoologische Mededelingen. Vol.41. P.15-42.

Helsdingen P.J. 1986. World distribution of Linyphiidae // Proceedings of the Ninth International Congress of Arachnology, Panama 1983, Smithsonian Institution Press, Washington D.C. P.121-126.

Holm A. 1979. A taxonomic study of European and East African species of the genera Pelecopsis and Trichopterna (Araneae, Linyphiidae), with descriptions of a new genus and two new species of Pelecopsis from Kenya // Zoologica Scripta. Vol.8. P.255-278.

Hormiga G. 1994. Cladistics and the comparative morphology of linyphiid spiders and their relatives (Araneae, Araneoidea, Linyphiidae) // Zoological Journal of the Linnean Society. Vol.111. P.1-71.

Hormiga G. 2000. Higher level phylogenetics of erigonine spiders (Araneae, Linyphiidae, Erigoninae) // Smithsonian Contributions to Zoology. No.609. P.1-160.

Merrett P. 1963. The palpus of male spiders of the family Linyphiidae // Proceedings of the Zoological Society of London. Vol.140. P.347-467.

Tanasevitch A.V. 2018. A new Tapinocyba Simon, 1884 from southern China (Aranei: Linyphiidae) // Arthropoda Selecta. Vol.27. No.2. P.169-171.

Responsible editor K.G. Mikhailov 